\title{
Effect of monensin on rumen fermentation and digestion and milk production in lactating dairy cows
}

\author{
E.D. Mackintosh', R.H. Phipps', J.D. Sutton', \\ D.J. Humphries' and J.I.D. Wilkinson ${ }^{2}$
}

\author{
'Centre for Dairy Research. Department of Agriculture, \\ The University of Reading \\ PO Box 236, Reading, RG6 6AT, United Kingdom \\ 'Elanco Animal Heallh, a Division of Eli Lilly \& Company \\ Greenfield, Indiana, 46/40-0708. USA
}

(Received 13 May 2002: accepted 2 Angust 2002)

\begin{abstract}
Four Holstein-Friesian dairy cows, fitted with ruminal and duodenal cannulas, were used to evaluate the effect of 0 and $300 \mathrm{mg} / \mathrm{d}$ monensin offered with a total mixed ration (TMR) on rumen fermentation, site of nutrient digestion, and milk yield and composition. Indigestible markers chromium EDTA and ytterbium acctate were ruminally infused and their concentration measured at the duodenum to determine digesta flow rates. Choice of method of processing digesta samples caused large differences in the variation in digesta flow calculations. Monensin increased rumen molar proportions (mmol/total mol) of propionic acid (2!4 vs 268) and reduced those of acetic (622 vs 583 ) and n-butyric acid (134 vs 119). The values recorded for monensin treated cows for nitrogen (N) digested in the rumen, flow of total $N$ and non-ammonia $N$ (NAN) to the duodentm and $N$ voided in the faces were 5.6,6.1,7.1 and 16.0\% units lower compared with the control. Monensin decreased starch digestion in the rumen $(9.4 \%$ units), increased starch flow to the duodenum $(0.5 \mathrm{~kg} / \mathrm{d})$ but did not alter total tract digestion. Monensin had no significant effect on rumen or total tract digestion of organic matter (OM), acid detergent fibre (ADF) and nitrogen. Milk yield was increased numerically by $1.9 \mathrm{~kg} / \mathrm{d}$, and milk fat and milk protein contents were reduced by 3.9 and $1.5 \mathrm{~g} / \mathrm{kg}$, respectively, but yields of fat and protein were unaffected.
\end{abstract}

KEY WORDS: monensin, rumen fermentation, digestion, dairy cows

\section{INTRODUCTION}

Numerous studies have shown that one of the major effects of including monensin in ruminant diets is a reduction in molar proportions of acetate and butyra- 
te and a concomitant increase in propionate. These changes have been associated with improved efficiency, increased milk yield and a reduction in milk fat content in lactating dairy cows by amongst others McGuffy and Giner-Chavez (1998) and Phipps et al. (2000). Studies have also demonstrated the positive benefits on animal health (Wade et al., 1996; Duffield et al., 1999).

While a number of recent experiments (Wade et al., 1996; McGuffy and GinerChavez 1998; Phipps et al., 2000) have reported the effects of monensin on milk production responses, few studies have examined its effect on rumen digestion and metabolism with fistulated lactating dairy cows (Haïmoud et al., 1995).

The aim of the current experiment was to determine the effects of monensin on rumen fermentation, digestion in the rumen and total tract and milk production using four rumen and duodenal fistulated lactating dairy cows. In addition the study also compared the effects of different methods of processing duodenal digesta on concentrations of markers.

\section{MATERIAL AND METHODS}

\section{Animals}

Four multiparous Holstein-Friesian cows, 150 days in milk and weighing approximately $630 \mathrm{~kg}$, were used in the study. Cows were fitted with permanent cannulas in the rumen and proximal duodenum. The cows were individually restrained in tie stalls and housed in a purpose built dairy research unit. Temperature was regulated by blower fans and plastic wind socks. Fresh water and mineral blocks were available at all times. The cows were weighed at the beginning and the end of the experiment.

\section{Experimental design}

The experiment consisted of four periods. Within each period two cows were allocated the control diet $(0 \mathrm{mg}$ monensin/d) and two the treated diet $(300 \mathrm{mg}$ $\operatorname{monensin} / \mathrm{d}$ ). The treatments were randomly allocated using a random number table. Treatments were reversed with each subsequent period according to a $2 \times 4$ (two treatments and four periods) changeover design. Each period lasted four weeks, with the first three weeks for change over and adaptation and week 4 for experimental measurements. Due to mastitis one cow was withdrawn from the experiment at the end of period 3. Cows were milked twice daily at 06.30 and $15.30 \mathrm{~h}$ and yields recorded using a 'Tru-Test' milk recorder (Tru-Test Distributors Limited, New Zealand) connected to a direct-to-line milking system. 


\section{Diets}

Throughout the experiment all cows were offered the same TMR in two equal batches at 08.30 and $16.30 \mathrm{~h}$. The TMR contained on a DM basis, 51.3, 13.5, 32.6 and $2.6 \%$ maize silage, grass silage, concentrate (soyabean meal, rapeseed meal, fish meal and minerals) and molasses, respectively. During the first $17 \mathrm{~d}$ of each period the TMR was offered ad libitum. Uneaten feed was removed at $08.00 \mathrm{~h}$ daily, weighed and discarded. Grass and maize silages were from standard crops harvested the previous season and ensiled in small bunkers and the concentrate meal was prepared on farm. The pelleted supplements, which were offered at the rate of $1 \mathrm{~kg} / \mathrm{d}$ in two $500 \mathrm{~g}$ portions at 08.30 and $16.30 \mathrm{~h}$, formed the experimental treatments and contained either 0 or $300 \mathrm{mg} / \mathrm{kg}$ monensin ${ }^{\dagger}$. Following preparation at a commercial feed mill, samples of both pelleted supplements were assayed for monensin.

\section{Experimental procedures}

From day 18 onwards of each experimental period, the amount of TMR offered was adjusted to equal the mean total daily intake/cow from the previous six days. The following sequence was adopted during each experimental period. Duodenal digesta flow was measured using the Faichney (1975) dual-marker method in which solutions of chromium $(\mathrm{Cr})$ EDTA and ytterbium $(\mathrm{Yb})$ acetate were infused into the rumen in separate lines at $40 \mathrm{ml} / \mathrm{h}$ as digesta flow markers (McAllan et al., 1994). Infusions began on day 17 of each period and were preceded by the addition of primer doses of $1.75 \mathrm{~g}$ CrEDTA and $1.08 \mathrm{~g} \mathrm{Yb}$ acctate, each in $500 \mathrm{ml}$ solution. Infusion solutions contained $3.5 \mathrm{~g} \mathrm{Cr} / \mathrm{l}$ and a concentration of $\mathrm{Yb}$ based on the amount of DM being offered to each cow (50 mg Yb/kg DM). Duodenal samples (approximately $800 \mathrm{~g}$ ) and faecal grab samples (approximately $500 \mathrm{~g}$ ) were taken every $6 \mathrm{~h}$ on days 24,25 and 26 with sampling being $2 \mathrm{~h}$ later on successive days so that a sample was obtained for every $2 \mathrm{~h}$ of a $24 \mathrm{~h}$ period. The samples were stored as single bulks for each cow in each period at $4^{\circ} \mathrm{C}$. At the end of each experimental period the duodenal digesta samples were processed using three alternative methods. To provide three digesta samples of closely similar composition to compare digesta-processing techniques, each bulked digesta sample was split into solid and liquid fractions using a plastic kitchen sieve. Both fractions were then divided into three and the solid and liquid fractions were then reconstituted to give three equal samples. Approximately $1 \mathrm{~L}$ of each sample was then processed by one of the three methods during which sub-samples were taken for further preparation:

\footnotetext{
${ }^{+} 300 \mathrm{~g}$ Romensin $\mathrm{G} 100^{\mathrm{k}}$ premix/tonne supplement (Elanco Animal Health, Basingstoke, UK)
} 
1. not homogenised but stirred vigorously with a spoon to produce sub-samples of whole digesta (WD) and by low-speed centrifugation ( $3360 \mathrm{~g}$ for $30 \mathrm{~min}$ ), a solids rich fraction but excluding most of the bacterial residues (CD),

2. homogenised using a multi-purpose laboratory mixer fitted with a stainless steel disintegrating head for solid material of animal or vegetable origins (Silverson Machines Ltd, Chesham, Bucks, UK) followed by low-speed centrifugation ( $3360 \mathrm{~g}$ for $30 \mathrm{~min}$ ) to produce similar WD and CD fractions to method 1 ,

3. homogenised as in method 2 but the CD fraction prepared by high-speed centrifugation $(20,500 \mathrm{~g}$ for $30 \mathrm{~min})$ to ensure that most of the microbial fraction was included in the solid fraction.

All the digesta samples were subsequently dried at $60^{\circ} \mathrm{C}$ for $72 \mathrm{~h}$. Feed and faecal samples were mixed and sub-samples were taken for drying at $60^{\circ} \mathrm{C}$ for $48 \mathrm{~h}$ or frozen at $-20^{\circ} \mathrm{C}$ for subsequent analysis. All dried samples were ground through a $1 \mathrm{~mm}$ screen using a small laboratory mill before analysis.

Rumen samples were taken at hourly intervals from 08.00 to 24.00 h on day 24 . The $\mathrm{pH}$ was measured immediately and separate sub-samples were stored at $-20^{\circ} \mathrm{C}$ for subsequent analysis for ammonia after acidification with concentrated sulphuric acid, and volatile fatty acids (VFA).

Milk composition was measured in a.m. and p.m. samples from each cow on at least four consecutive days starting on day 23 of each period.

\section{Analytical}

Samples were analysed by standard laboratory methods described previously (Sutton et al., 1997; Abdalla et al., 1999). Crude protein content was determined by Kjeldahl technique for the fresh forages and the faeces but by Leco combustion method (Leco Corporation, St. Joseph, Milkaukce) for dried concentrates and digesta. $\mathrm{Cr}$ content of duodenal digesta and infusates were measured by atomic absorption spectrometry (AAS) and $\mathrm{Yb}$ content by sequential inductively coupled plasma analysis (ICP). True digesta flow was determined mathematically from the reconstitution value $(R)$ calculated from the measured concentrations of $\mathrm{Yb}$ and $\mathrm{Cr}$ in the WD and CD digesta fractions (Faichney, 1975). The R factor is described by Faichney (1975) as "a measure of the number of units of fluid that must be added to (or removed from) one unit of digesta to obtain true digesta". True digesta can then be obtained by physical reconstitution or it can be calculated mathematically as in the present experiment. In a fully representative sample, the $\mathrm{R}$ value should be 0 but in practice values are commonly in the range \pm 0.3 unit. 


\section{Statistical analyses}

Data were subjected to analysis of variance using the General Lincar Model procedure of the SAS Institute Inc. Treatment, cow and period were sources of variation and treatment was the main effect.

\section{RESULTS}

\section{Duodenal digesta processing method}

The $\mathrm{R}$ values were used to rank the three duodenal digesta processing methods. Methods 1 and 3 gave lower R values than method 2 but the variation was far greater for methods 2 and 3, both of which involved homogenisation, than for method 1 which involved no homogenisation and low speed centrifugation (Table 1). Closer examination of the results from the three methods suggested that the large variation in $R$ values in methods 2 and 3 was associated with high chromium concentrations. In contrast, there was little difference in the $\mathrm{Yb}$ concentrations between the three methods of processing the digesta.

TABLE !

Mean chromium and ytterbium concentrations ( $\mu \mathrm{g} / \mathrm{g}$ DM) for three duodenal digesta processing methods in whole (WD) and centrifuged (CD) duodenal digesta and the reconstitution values

\begin{tabular}{llccc}
\hline & & \multicolumn{3}{c}{ Processing methods $^{1}$} \\
\cline { 3 - 5 } & & 1 & 2 & 3 \\
\hline \multirow{2}{*}{ Chromium } & Whole digesta & $234(37.4)^{2}$ & $320(112.5)$ & $301(59.9)$ \\
& Centrifuged digesta & $80(12.3)$ & $160(101.9)$ & $128(84.6)$ \\
& & & & $57(8.3)$ \\
\multirow{3}{*}{ Ytterbium } & $52(8.1)$ & $54(9.2)$ & $71(11.5)$ \\
& Whole digesta & $61(13.4)$ & $68(13.0)$ & \\
& Centrifuged digesta & & & $0.357(2.160)$ \\
\hline
\end{tabular}

${ }^{1} \mathrm{I}=$ not homogenised, low speed centrifugation

2 = homogenised, low speed centrifugation

3 = homogenised, high speed centrifugation

${ }^{2}$ figures in parentheses $=$ standard deviation

Since the reliability of the marker results was confirmed by repeat analysis, the results for duodenal digesta processing method 1 were used in all the subsequent digesta flow calculations. To try to establish the cause of the high $\mathrm{Cr}$ values in some of the digesta samples, methods of sample processing were examined in detail and comparisons made of AAS and ICP methods of analysis (Mackintosh, 1998). It was concluded from these studies that the high $\mathrm{Cr}$ values were associated with the ho- 
mogenisation procedure, presumably reflecting contamination of the samples by physical or chemical means with $\mathrm{Cr}$ from the steel of the homogeniser blades.

\section{Rumen VFA and pH patterns}

Although monensin supplementation had no effect on rumen liquor $\mathrm{pH}$ or total VFA or $\mathrm{NH}_{3}$ concentration, it significantly $(\mathrm{P}<0.05)$ reduced the molar proportions of acetic and butyric acid while those of propionic, iso-butyric and iso-valeric acids were increased $(\mathrm{P}<0.05)$, with a consequential reduction $(\mathrm{P}<0.01)$ in lipogenic:gluconeogenic ratio $(\mathrm{A}+\mathrm{B} / \mathrm{P})$ (Table 2$)$.

TABLE 2

Effect of monensin $(300 \mathrm{mg} / \mathrm{d})$ on the end products of fermentation in the rumen

\begin{tabular}{lccc}
\hline & \multicolumn{2}{c}{ Monensin, $\mathrm{mg} / \mathrm{d}$} & \multirow{2}{*}{ SED $^{1}$} \\
\cline { 2 - 3 } & 0 & 300 & 0.04 \\
\hline pH & 6.0 & 5.9 & 4.6 \\
Total VFA, mmol/ & 134 & 138 & \\
VFA, mmol/total mol & & & 10.5 \\
acetic (A) & $622^{\mathrm{a}}$ & $583^{\mathrm{b}}$ & 1.4 \\
propionic (P) & $214^{\mathrm{h}}$ & $28^{\mathrm{a}}$ & 0.3 \\
iso-butyric & $6^{\mathrm{h}}$ & $7^{\mathrm{a}}$ & 5.4 \\
n-butyric (B) & $134^{\mathrm{a}}$ & $19^{\mathrm{b}}$ & 0.8 \\
iso-valeric & $3^{\mathrm{b}}$ & $6^{\mathrm{a}}$ & 0.7 \\
n-valeric & 14 & 15 & 1.6 \\
n-caproic & 5 & 3 & 0.20 \\
(A+B):P ratio & & & 0.51 \\
Ammonia, mmol/1 & $3.6^{\mathrm{a}}$ & $2.7^{\mathrm{b}}$ & \\
\hline
\end{tabular}

' SED = standard error of the difference between two treatment means

ab means within a row with different superscripts differ $(\mathrm{P}<0.05)$

\section{Rumen digestion}

There was no treatment effect on intake of DM, OM, starch and ADF, or passage of OM and ADF to the duodenum (Table 3). However, the flow of undigested starch to the duodenum increased $(\mathrm{P}<0.05)$ by $29 \%$ units and digestion of starch in the rumen decreased $(\mathrm{P}<0.05)$ by $15 \%$ units. The effect of similar intakes of OM, starch and ADF coupled with reduced faccal output in monensin treated cows resulted in increased total tract digestibility, although these differences were not significant. This indicates that more starch was digested in the small and/or large intestine of monensin fed cows when compared with control fed cows. Although none of the $\mathrm{N}$ parameters measured was significantly affected by monensin supplementation, there were numerical differences (Table 4$)$. Monensin reduced $(\mathrm{P}>0.05)$ 
$\mathrm{N}$ digested in the rumen, the flow of total $\mathrm{N}$ and $\mathrm{NAN}$ to the duodenum and $\mathrm{N}$ voided in the faeces by $5.6,6.1,7.1$ and $16.0 \%$ units, respectively, but increased total tract $\mathrm{N}$ digestion by $4.8 \%$ units.

TABLE 3

Effect of monensin $(300 \mathrm{mg} / \mathrm{d})$ on the site and extent of organic matter, starch and acid detergent fibre digestion

\begin{tabular}{|c|c|c|c|}
\hline & \multicolumn{2}{|c|}{ Monensin, $\mathrm{mg} / \mathrm{d}$} & \multirow[t]{2}{*}{$\mathrm{SED}^{1}$} \\
\hline & 0 & 300 & \\
\hline Dry matter intake & 21.0 & 20.8 & 0.19 \\
\hline \multicolumn{4}{|l|}{ Organic matter } \\
\hline intake, $\mathrm{kg} / \mathrm{d}$ & 20.3 & 20.2 & 0.18 \\
\hline duodenal flow, $\mathrm{kg} / \mathrm{d}$ & 12.8 & 12.3 & 0.82 \\
\hline ruminal digestion, $\%$ & 37.1 & 38.6 & 4.04 \\
\hline faecal output, $\mathrm{kg} / \mathrm{d}$ & 6.2 & 5.5 & 0.43 \\
\hline total tract digestion, $\%$ & 69.4 & 72.8 & 2.13 \\
\hline \multicolumn{4}{|l|}{ Starch } \\
\hline intake, $\mathrm{kg} / \mathrm{d}$ & 4.9 & 4.8 & 0.04 \\
\hline duodenal flow, $\mathrm{kg} / \mathrm{d}$ & $1.7^{\mathrm{b}}$ & $2.2^{\mathrm{a}}$ & 0.17 \\
\hline ruminal digestion, $\%$ & $64.6^{a}$ & $55.2^{b}$ & 3.04 \\
\hline faecal output, $\mathrm{kg} / \mathrm{d}$ & 0.4 & 0.3 & 0.03 \\
\hline total tract digestion, $\%$ & 92.7 & 93.5 & 0.68 \\
\hline \multicolumn{4}{|l|}{ Acid detergent fibre } \\
\hline intake, $\mathrm{kg} / \mathrm{d}$ & 3.7 & 3.6 & 0.03 \\
\hline duodenum flow, $\mathrm{kg} / \mathrm{d}$ & 2.6 & 2.4 & 0.23 \\
\hline ruminal digestion, $\%$ & 30.5 & 34.4 & 6.34 \\
\hline faecal output, $\mathrm{kg} /$ day & 2.0 & 1.9 & 0.13 \\
\hline total tract digestion, $\%$ & 44.6 & 48.5 & 3.59 \\
\hline
\end{tabular}

${ }^{1}$ SED $=$ standard error of the difference between two treatment means

${ }^{\mathrm{ab}}$ means within a row with different superscripts differ $(\mathrm{P}<0.05)$

TABLE 4

Effect of monensin $(300 \mathrm{mg} / \mathrm{d})$ on the site and extent of nitrogen $(\mathrm{N})$ digestion

\begin{tabular}{lccc}
\hline & \multicolumn{2}{c}{ Monensin, $\mathrm{mg} / \mathrm{d}$} & $\mathrm{SED}^{1}$ \\
\cline { 2 - 4 } & 0 & 300 & \\
\hline $\mathrm{N}$ intake, g/day & 636 & 631 & 5.6 \\
Passage to duodenum, g/d & & & \\
$\quad$ total N & 693 & 650 & 29.7 \\
$\quad$ non-ammonia N & 644 & 601 & 28.7 \\
Ruminal N digestion, \% & -9.0 & -3.0 & 4.9 \\
Faecal output, g/day & 200 & 168 & 15.5 \\
Total tract digestion, $\%$ & 68.6 & 73.4 & 2.42 \\
\hline
\end{tabular}

$\mathrm{SED}=$ standard error of the difference between two treatment means 


\section{Milk production}

The effects of monensin on milk production are shown in Table 5. Its inclusion in the TMR increased $(\mathrm{P}=0.08)$ milk yield by $1.9 \mathrm{~kg} / \mathrm{d}$ and reduced $(\mathrm{P}<0.05)$ milk fat and protein contents from 48.6 to 44.7 and 36.3 to $34.8 \mathrm{~g} / \mathrm{kg}$, respectively. Lactose content was unaffected by monensin. Although monensin significantly reduced milk fat and protein content, the increase in milk yield meant that milk fat and protein yields were unaffected $(\mathrm{P}>0.05)$.

TABLE 5

Effect of monensin $(300 \mathrm{mg} / \mathrm{d})$ on milk yield and composition

\begin{tabular}{lccc}
\hline \multirow{2}{*}{ Indices } & \multicolumn{2}{c}{ Monensin, $\mathrm{mg} / \mathrm{d}$} & \\
\cline { 2 - 3 } & 0 & 300 & SED $^{\mathrm{I}}$ \\
\hline $\begin{array}{l}\text { Yield, } \mathrm{kg} / \text { day } \\
\text { milk } \\
\text { fat }\end{array}$ & 27.4 & 29.3 & 0.92 \\
protein & 1.28 & 1.25 & 0.032 \\
lactose & 0.99 & 1.01 & 0.022 \\
& $1.25^{\mathrm{b}}$ & $1.34^{\mathrm{a}}$ & 0.044 \\
Content, g/kg & & & \\
fat & & & \\
protein & $48.6^{\mathrm{a}}$ & $44.7^{\mathrm{b}}$ & 0.85 \\
lactose & $36.3^{\mathrm{a}}$ & $34.8^{\mathrm{b}}$ & 0.53 \\
\hline
\end{tabular}

1 SED $=$ standard error of the difference between two treatment means

${ }^{\mathrm{a} b}$ means within a row are significantly different $(\mathrm{P}<0.05)$

\section{DISCUSSION}

The infusion of the indigestible markers $\mathrm{Cr}$ EDTA and $\mathrm{Yb}$ acetate was shown to be a reliable method of determining duodenal digesta flow in sheep (Siddons et al., 1985) and has subsequently yielded satisfactory estimates of digestion in the rumen of lactating cows (McAllan et al., 1994; Abdalla et al., 1999). The mean R values recorded in the current experiment were in the expected range when using processing method 1 and 3, but the variability was far greater with methods 2 and 3 than method 1. The use of the homogeniser was introduced in methods 2 and 3 in order to try to reduce the problems of obtaining representative samples of duodenal digesta when using method 1 . However, there was strong evidence that it was the stainless steel homogeniser blades that were the source of the higher $\mathrm{Cr}$ concentrations and the so variable $\mathrm{R}$ values.

Faecal recoveries of $\mathrm{Yb}$ of 89,93 and $94 \%$ measured in three of the cows in the present study are slightly higher than the values of 84 and $88 \%$ reported in other dairy cows (Haïmoud et al., 1995) but were lower than the mean recovery of $104 \%$ 
found in wether sheep (Siddons et al., 1985). There is no obvious explanation for these different recoveries.

The current work confirms earlier studies (Haïmoud et al., 1995; Phipps et al., 2000 ) showing that the inclusion of $200-300 \mathrm{mg} / \mathrm{d}$ of monensin in dairy cows diets had a major influence on rumen fermentation, resulting in an increase in the molar proportion of propionic acid and a concomitant reduction in acetic and butyric acids, and in the lipogenic:gluceogenic ratio. Since acetic acid is the primary lipogenic precursor, any reduction in its molar proportion may directly limit mammary gland de novo milk fat synthesis. The effect of monensin in significantly reducing milk fat content in the current experiment is attributed to the significant changes in the end products of rumen fermentation.

The lack of effect of monensin in the current study on OM and fibre digestibility agrees with some studies (Chalupa, 1988) but conflicts with the negative effects noted in others (Haïmoud et al., 1995). The effects of monensin on fibre digestibility are still unclear.

The reduction in rumen starch digestion from 64.6 to $55.2 \%$ in monensin treated cows is very similar to the earlier results (Haïmoud et al, 1995), obtained under similar experimental conditions. The fact that total tract starch digestion was unaffected by monensin, indicates that its digestion in the small and/or large intestine was increased which could result in increased efficicncy of energy utilization. The likely explanation for the reduction in rumen starch digestion lies in the inhibition of the rumen bacterium Streptococcus bovis. This gram-positive bacterium is one of the major rumen starch fermenters, synthesising lactic acid, and is highly sensitive to monensin (Russell and Stobel, 1989). The effects of monensin in increasing rumen propionic acid molar proportion, and increasing starch digestion in the small intestine could explain reports of raised blood glucose and reduced circulating ketone levels in cattle receiving with monensin (McGuffy and Giner-Chavez, 1998). Recent studies have clearly established that these effects can reduce the risk of sub-clinical and clinical ketosis in the peri-parturient transition cow (Wade et al., 1996; Duffield et al., 1999).

In reviewing the effects of monensin on protein metabolism Chalupa (1988) noted that it generally reduced ruminal degradation of dietary protein, decreased ruminal $\mathrm{NH}_{3} \mathrm{~N}$ concentration and increased true protein flow to the small intestine. Although the current study did not establish significant effects of monensin on site and extent of nitrogen digestion it should be noted that the rumen $\mathrm{NH}_{3} \mathrm{~N}$ concentration was numerically lower in monensin fed cows which may indicate a decrease in ruminal protein degradation. However it should be noted that there were no treatment effects on rumen or whole tract nitrogen digestion, the values of which were similar to those noted earlier (Haïmoud et al., 1995).

The effect of monensin on milk yield and composition was marked. The milk yield response of $1.9 \mathrm{~kg} / \mathrm{d}$ was substantial. Although it was not significant it is wi- 
thin the range $(0.4$ to $2.8 \mathrm{~kg} / \mathrm{d})$ noted in a number of recent studies in which dairy cows received 200-330 mg monensin/d (Lynch et al., 1990; Haïmoud et al., 1995; Hayes et al., 1996; Wade et al., 1996; McGuffy and Giner-Chavez, 1998; Phipps et al., 2000). The increase in milk yield is attributed to changes in rumen fermentation, which increased the supply of gluconeogenic precursors. Variation in milk yield response has been attributed to plane of nutrition (Lean et al., 1994), with little or no response recorded when cows grazed poor quality native pasture but a substantial response was noted when cows were offered good quality fertilized pasture.

The effect of monensin in reducing milk fat content was not unexpected given its now well-established effect on rumen VFA proportions in lactating dairy cows. The decline in milk fat content of $3.9 \mathrm{~g} / \mathrm{kg}$ noted in the current study when cows were supplemented with $300 \mathrm{mg}$ monensin/d is very similar to those recorded at Reading using similar diets and the same dose rate (Phipps et al., 2000). However, it should be noted that the reduction in milk fat content in cows supplemented with $300 \mathrm{mg}$ monensin/d has varied from 1.0 to $5.6 \mathrm{~g} / \mathrm{kg}$ (Lynch et al., 1990; Hayes et al., 1996; Wade et al., 1996; McGuffy and Giner-Chavez, 1998; Phipps et al., 2000). This variation may be related to diet composition, as work has shown that the effect of monensin on rumen fermentation and milk fat depression is diet dependent (Ramanzin et al., 1997; Mackintosh, 1998). The decrease in milk fat content was offset by an increase in milk yield resulting in no effect on milk fat yield.

The biochemical events surrounding milk protein synthesis are complex. Although workers have noted that while the use of monensin does not markedly affect the amount of total $\mathrm{N}$ leaving the rumen, microbial protein synthesis may be reduced (Haïmoud et al., 1995) with the result that the relative proportions of dietary and microbial protein in duodenal digesta are altered (Chalupa, 1988). A recent review (Mackintosh, 1998) reported that in 12 out of 15 dairy cow studies, milk protein content was reduced by monensin, but the differences although marked, were generally not significant. In the current study, however the reduction in milk protein content $(1.5 \mathrm{~g} / \mathrm{kg}$ ) was significant, confirming earlier results (Phipps et al., 2000). These results are attributed to dilution effects, as while monensin reduced milk protein content the production of milk protein precursors had not been altered as yield of milk protein was unaffected.

\section{CONCLUSIONS}

The experiment showed that duodenal digesta processing method is important for correct marker analysis. Under the conditions described, homogenising digesta was found to increase $\mathrm{Cr}$ content. The supplementation of monensin to lactating dairy cows increased rumen propionic acid proportion while decreasing proportions of acetic and butyric acids. Monensin decreased ruminal starch digestion and increased starch flow to the duodenum without significantly affecting rumen 
digestion of either $\mathrm{OM}$, fibre or $\mathrm{N}$. The use of monensin in dairy cows diets increased milk yicld and reduced milk fat and milk protein content but did not affect yield of milk constituents.

\section{REFERENCES}

Abdalla A L.. Sutton J.D., Phipps R.11., I lumphries D.J., 1999. Digestion in the rumen of lactating dairy cows given mixtures of urea-treated whole-crop wheat and grass silage. Anim. Sci. 69, 203-212

Chalupa W., 1988. Manipulation of rumen fementation. In: W. Haresign, D.J.A. Cole (Editors). Recent Developments in Ruminant Nutrition. Nottingham University Press, Nottingham (UK), pp. $1-18$

Duffield T.F., Sandals D.K., Leslie E., Lissemore K., McBride B.W., Lumsden J.H., Dick P., Bagg R., 1999. Efficacy of monensin for the prevention of subclinical ketosis in lactating dairy cows. J. Dairy Sci. 81, 2866-2873

Faichney G.J.. 1975. The use of markers to partition digestion within the gastro-intestinal tract of ruminants. In: W. McDonald, A.C.I. Warner (Editors). Digestion and Metabolism in the Ruminant. I. University of New England Publishing Unit, Armidale (Australia), pp.277-291

Haïmoud D.A., Vernay M., Bayourthe C., Moncoulon R., 1995. Avoparcin and monensin effects on the digestion of nutrients in dairy cows fed a mixed diet. Can. J. Anim. Sci. 75, 379-385

Hayes D.P., Pfeiffer D.U., Williamson N.B., 1996. Effect of intraruminal monensin capsules on reproductive-performance and milk-production of dairy-cows fed pasture. J. Dairy Sci. 79, $1000-1008$

Lean I.J., Curtis M., Dyson R., Lowe B., 1994. Effects of sodium monensin on reproductive performance of dairy cattle. 1. Effects on conception rates, calving-to-conception intervals, calving-to-heat and milk production in dairy cows. Aust. Vet. J. 71, 273-277

Lynch G.A., Hunt M.E., McCutcheon S.N., 1990. A note on the effect of monensin sodium administered by intraruminal controlled-release devices on productivity of dairy cows at pasture. Anim. Prod. 51, 418-421

Mackintosh E.D., 1998. The effect of monensin on in vitro rumen fermentation and in vivo rumen and total tract digestion and milk production in the dairy cow. PhD. Thesis, The University of Reading, Reading (UK)

McAllan A.B., Sutton J.D., Beever D.E., Napper D.J., 1994. Rumen fermentation and duodenal nutrient flow in lactating cows receiving two types of silages with two levels of concentrates. Anim. Feed Sci. Tech. 46, 277-291

McGuffy R.K., Giner-Chavez. B., 1998. Lactation performance of dairy cows receiving monensin and a sustained release formulation of methionyl bovine somatotropin. J. Dairy Sci. 81, Suppl. 1,261 (Abstr.)

Phipps R.H., Wilkinson J.I.D., Jonker L.J., Tarrant M., Jones A.K., Hodge A., 2000. Effect of monensin on milk production of Holstein-Friesian dairy cows. J. Dairy Sci. 83, 2789-2794

Ramanzin M., Batloni L., Schiavon S., Bittante G., 1997. Effect of monensin on milk production and efficiency of dairy cows fed two diets differing in forage to concentrate ratios. J. Dairy Sci. $80,1136-1142$

Russel J.B., Stobel H.J., 1989. Effect of ionophores on ruminal fermentation. Appl. Environ. Microbiol. $55,1-6$

SAS ${ }^{\text {t }}$ 1992. Users Guide: Statistics Version 6.07 Edition. SAS Inst., Inc., Cary, NC 
Sauer F.D., Kramer J.K.G, Cantwell W.J., 1989. Antiketogenic effects of monensin in early lactation. J. Dairy Sci. 72, 436-442

Siddons R.C., Paradine J., Beever D.E., Cornell P.R., 1985. Ytterbium acetate as a particulate-phase digesta flow marker. Brit. J. Nutr. 54, 509-519

Sution J.D., Abdalla A.L., Phipps R.H., Cammell S.B., Humphries D.J., 1997. The effect of the replacement of grass silage by increasing proportions of urea-treated whole-crop wheat on food intake and digestibility and milk production by dairy cows. Anim. Sci. 65, 343-351

Wade L., Granzin B., Lowe B., 1996. The effect of monensin in dairy cow rations on milk production and in reducing the severity of ketosis. In: Proceedings of 19 th World Buiatrics Conference, Edinburgh (UK), pp. 289-290

\section{STRESZCZENIE}

\section{Wplyw dodatku monensinu na fermentację $\mathrm{i}$ trawienie w żwaczu oraz na produkcję mleka przez krowy ras mlecznych}

Doświadczenie przeprowadzono na 4 krowach mlecznych holsztyno-fryzach, z przetokami do żwacza i dwunastnicy, celem zbadania wpływu dodatku monensinu $(0$ i $300 \mathrm{mg} / \mathrm{d}$ ) do pełnoporcjowych dawek (TMR) na fermentację i przebieg trawienia w żwaczu oraz produkcję i skład mleka. Niestrawne składniki: EDTA chromu i octan iterbu podawano do żwacza jako markery i na podstawie ich stężenia w dwunastnicy oznaczano tempo przepływu tresci pokarmowej. Zastosowana metoda oznaczania przepływu treści pokarmowej była przyczyną dużych różnic przy obliczaniu jej przepływu. Dodatek monensinu zwiększyl molowy udział (mmol/mol sumy LKT) kwasu propionowego (214 vs 268) a obniżył octowego (22 vs 583 ) i kwasu n-masłowego (134 vs 119). Uzyskane wartości, dotyczące trawienia azotu (N) w żwaczu, przepływu N całkowitego i N nie-amonowego (NAN) do dwunastnicy i $\mathrm{N}$ wydalonego w kale u krów otrzymujących dodatek monensimu były 05,$6 ; 6,1$; 7,1 i 16,0 jednostek procentowych mnicjsze niż u krów kontrolnych.. Monensin obuiżył także stopień trawienia skrobi w żwaczu $(0,94$, jednostki procentowej), zwiçkszył jej przcplyw do dwunastnicy $(0,5 \mathrm{~kg} / \mathrm{d})$, lccz nic spowodował zmian w trawieniu skrobi w calym przewodzie pokarmowym. Dodatek monensinu do paszy nie mial istotnego wpływu na trawienic substancji organicznej, ADF oraz $\mathrm{N}$ ogólnego w całym przewodzie pokarmowym. Wydajność mleka wzrosła o $1,9 \mathrm{~kg} / \mathrm{d}$, a zawartość tłuszczu i białka mleka została obnizona o 3,9 i 1,5 g/kg, odpowiednio, lecz całkowita produkcja tłuszczu i białka mlcka nic ulcgła zmianie w porównaniu z kontrolą. 